\title{
A NEW METHOD OF COUNTING PHOCA VITULINA SSP. STEJNEGERI (PHOCIDAE, CARNIVORA) ON THE COMMANDER ISLANDS (RUSSIA)
}

\author{
Evgeny G. Mamaev \\ Commander Islands Nature and Biosphere Reserve, Russia \\ e-mail: eumetopias@mail.ru
}

Received: 07.04.2018

\begin{abstract}
The Kuril Seal Phoca vitulina ssp. stejnegeri is a permanent inhabitant of the coast of the Commander Islands. The ecology of the Kuril Seal, and in particular, the features of its life cycle, the population structure and the level of fertility are poorly known. Most publications are devoted to the study of populations and spatial distribution of this animal on the islands. From June to October 2017, the current occurrence, features of spatial distribution, reproductive success of Phoca vitulina ssp. stejnegeri, seasonal dynamics of the number and the comparison of the accuracy of various methods of its counting have been carried out on Bering Island, Toporkov Island, Ariy Kamen Island, and at a site Bobroviye Kamni on Medniy Island. The material on the number and spatial distribution of the seals was collected using an unmanned aerial vehicle, quadrocopter (drone). In this study, the Kuril Seal was first counted on the islands by aerophotography. The determination of the population size has been carried out during the active reproduction phase of the Kuril Seal- from mid-June to $10^{\text {th }}$ July 2017. Our study showed that the accounted abundance of the Kuril Seal was 1543 individuals, including 343 pups on Bering Island and Toporkov Island. The abundance of Phoca vitulina ssp. stejnegeri on Medniy Island has been counted using the extrapolation method. It was estimated at 689 individuals. And the total number of this animal on the Commander Islands was 3344 individuals. For the first time, we obtained data on the proportion of pups (22.2\%) of the Kuril Seal on the Commander Islands in rookeries during the breeding season and the specific birth rate (17.4\%) was calculated. Up to $69.3 \%$ of the total number of Kuril Seals is present in large rookeries and only a small portion is presented by small groups or individuals. The proportion of pups born in large rookeries is $72 \%$. We found an increase of the Phoca vitulina ssp. stejnegeri abundance in the rookeries during the moult period (August). The abundance of individuals continued to grow in some rookeries in September. A comparison of the accuracy of the visual, traditional on the Commander Islands, method of animal counting with data obtained using the aerophotography method showed that in the case of counting from the boat, an observer can register an average of $67.7 \%$ of adult individuals and $24 \%$ of pups. In case of observation from the first seaside terrace of a shore, the observer can see $39.6 \%$ of individuals (adults and pups). And in case of observation from the slopes (height of $17 \mathrm{~m}$ and higher) the observer can see up to $62 \%$ of individuals (adults and pups). To discuss the long-term dynamics of the number of Kuril Seals on the Commander Islands it is required to conduct a detailed analysis of all available data, as they were collected by using different methods, which are not correctly comparable with the newly obtained results.
\end{abstract}

Key words: abundance, birth rate, counting method, Kuril Seal, Red Data Book, rookery, seal

\section{Introduction}

Phoca vitulina Linnaeus, 1758 is a species distributed circumpolarly. It is presented by five subspecies: Phoca subsp. concolor De Kay, 1842, Phoca subsp. mellonae Doutt, 1942, Phoca subsp. richardii Gray, 1864, Phoca subsp. stejnegeri, and Phoca subsp. vitulina Linnaeus, 1758 (Lowry, 2016). The subspecies Kuril Seal Ph. subsp. stejnegeri inhabits the Far Eastern waters of Russia, including the Commander Islands. Taking into account the great subspecies diversity and wide range - from the Atlantic Ocean basin to the Pacific Ocean - Phoca vitulina has developed in different parts of the range specific biological features, both in terms of breeding time, moulting time, use of the coastal strip, adaptation to tidal activity of the ocean, and many others. The Kuril Seal is listed in the Red Data Book of the Russian Federation.
The Kuril Seal depends extremely on the daily activity rhythms on tides. So, the animals come out for a rest on bare reefs or beaches at low tide. However, the number of the seals released to rest is significantly affected by various environmental factors, such as wind direction and speed, sea waves, precipitation, temperature and even cloudiness (Pauli \& Terhune, 1987; Brasseur et al., 1996; Grellier et al., 1996; Reder et al., 2003; Simpkins et al., 2003; Granquist \& Hauksson, 2016). The number of seals on dry land depends on the season of the year (e.g., Granquist \& Hauksson, 2016). In addition, depending on the local morphological features of the shores, Phoca vitulina can form rookeries on the reefs, which are far from the bedrock coast. This makes it extremely difficult to count the number of individuals from the shore.

The most effective method for obtaining accurate data on the number of Kuril Seal is aerophotography using light-engine aircraft and helicopters (Thomp- 
son \& Harwood, 1990; Cronin et al., 2004). During a flight the researchers make photos and determine the abundance of animals using photographs.

The abundance investigation should be carried out at a certain time. According to Thompson et al. (2005), the best time for investigation is the period of two hours before the maximum low tide and two hours after the maximum low tide. According to Granquist \& Hauksson (2016), the most optimal time is the period of two hours before the maximum low tide and three hours after the maximum low tide. In some areas, the most optimal time is a period of 1.5 hours after the maximum tide (London et al., 2012). Thus, to plan the countings it is necessary to know the peculiarities of a rookery formation on a certain place.

As not all individuals can be on the coast at the time of low tide, to determine the total number of individuals, it is necessary to use the corrective amendments for the unaccounted part of the population. These correction factors may differ in various habitats. For instance, in the study of Phoca vitulina in Norway, Bjørge et al. (2007) used the correction factors from 1.25 to 1.75 at different locations (i.e., $57 \%$ of the whole population in the rookery). In California, the correction factor varied from 1.54 to 2.86 depending on the habitat (Harvey $\&$ Goley, 2011). Tagging of seal individuals is used to determine the correction factor.

In the Russian Far Eastern waters, Phoca vitulina ssp. stejnegeri inhabits the Kurile Islands, small area of the southeastern coast of Kamchatka Peninsula and the Commander Islands. Moreover, according to general estimates, about half of its Far Eastern population lives on the Commander Islands (Burkanov, 1988; Trukhin, 2009; Zagrebelny \& Fomin, 2012, 2014).

A large number of publications on Kuril Seal is devoted to the determination of the abundance of Phoca vitulina ssp. stejnegeri on the Commander Islands (Marakov, 1962, 1964, 1967; Pinigin \& Pryanishnikov, 1972; Mymrin et al., 1979; Burdin et al., 1991; Zagrebelny \& Fomin, 2012, 2014). In addition, there are many unpublished data on the countings of the abundance of Kuril Seal (Annual report on the work, 1976-2004; Chronicle of Nature, 1995-2010). In most cases, the abundance of Phoca vitulina ssp. stejnegeri was investigated from the coast and only in a few cases - from a boat. Considering the characteristics of the Kuril Seal rookeries and the coastal zone, we had certain difficulties arising in determining the accurate number of individuals. As a result, there was a lack of data on its reproductive success on Commander Islands. In addition, undoubtedly, mistakes of individual researchers influenced the counting results.

The spatial distribution of Phoca vitulina ssp. stejnegeri along the coasts of the Commander Islands is a well-studied issue. Therefore, the dynamics of the coast use by Kuril Seals can be traced since 1960s till present. On the contrary, data on the general biology of the Kuril Seal, its ecology on the Commander Islands, are not enough. So, only two publications (Marakov, 1967; Burdin et al., 1991) contain brief data on the breeding terms of Phoca vitulina ssp. stejnegeri on the Commander Islands. The interannual and seasonal dynamics of the Kuril Seal abundance on the individual rookeries was considered in Burdin et al. (1991).

Apart from Phoca vitulina ssp. stejnegeri, there is an insignificant number of Phoca largha Pallas, 1811, known from the coasts of the Commander Islands. Both animals are actually indistinguishable during the field studies. Traditionally, both species are studied together on the Commander Islands. In our study, we did not make any distinction between them either.

Due to the peculiarities of the Kuril Seal biology and numerous data on its abundance, we aimed to obtain accurate data on the abundance of $P h$ oca vitulina ssp. stejnegeri, including data on the number of pups. It is needed to obtain data on the birth rate, to determine correction factors for visual counting of animal abundance, and to calculate the absolute size of the Phoca vitulina ssp. stejnegeri population on the Commander Islands.

\section{Material and Methods}

Data were collected from 12.06.2017 to 18.10.2017. To determine the abundance, the data collected from 25.06.2017 to 10.07.2017 (breeding period of Phoca vitulina ssp. stejnegeri) were used, because they are more closely confined to the reefs and their number is at the maximum. Data were collected during the whole study period to compare the accuracy of different methods of counting and ascertaining of the seasonal (during different physiological stages of the life cycle of Phoca vitulina ssp. stejnegeri: the breeding period and the moult period) dynamics of the animal abundance in the largest areas. All investigations have been carried out by author.

To take aerophotographs of the seal rookeries, we used an unmanned aerial vehicle (quadrocopter). The «Phantom 4 Pro+» quadrocopter (drone) was used to determine the number of individuals. 
The focal distance of the camera lens is $8.8 \mathrm{~mm}$. During the survey, the flight altitude of the quadrocopter was $60 \mathrm{~m}$, and it was chosen empirically. Thus, in case of photographing from a height of $70 \mathrm{~m}$, the quality of the final photographs was not always suitable for counting the number of Kuril Seal individuals and detecting pups among reefs. Photographing from a height of less than $60 \mathrm{~m}$ caused trouble among individuals of Phoca vitulina ssp. stejnegeri due to the the noise of the working screws of the quadrocopter. In most cases, the quadrocopter flying at a height of $60 \mathrm{~m}$ did not cause any trouble, except in cases of almost total silence. Under these conditions, the Kuril Seals demonstrated anxiety during the flight. In this case, we raised the quadrocopter higher.

To study the rookeries available for land access, the quadrocopter has arrived from the side of the coastal terrace. For example, these areas are in the Severnoe and Severo-Zapadnoe rookeries, along the eastern coast of Bering Island (Bolshaya bay, Staraya Gavan bay, Buyanovskiy reef, etc.), Tonkiy cape (Fig. 1). Other rookeries have been surveyed from the seaside. For this purpose, we launched the quadrocopter from the boat at a distance of several hundred metres of the rookeries. Toporkov Island was examined either from the boat or by landing on it from the village on the traditional place. The rookery at Skovoroda cape was surveyed from the sea and by the quadrocopter launched from Cherniy cape. During the study period, the whole coastline of Bering Island, Toporkov Island and Ariy Kamen Island has been surveyed. Phoca vitulina ssp. stejnegeri was not found on Ariy Kamen Island.

Before the launching of the quadrocopter, Phoca vitulina ssp. stejnegeri has been investigated from the coastal terrace, slope or boat to estimate the accuracy of the visual counting method. For visual counting, we used binoculars «Canon $12 \times 36$ IS III» and a telescope, «Baush and Lomb 15-60 $\times 60$ » with a tripod. The counting of Phoca vitulina ssp. stejnegeri by the telescope has been carried out with magnification power at 20 times.

All countings of Phoca vitulina ssp. stejnegeri were made in periods with the maximum level of low tide, provided the appropriate weather conditions: wind speed - up to $10 \mathrm{~m} / \mathrm{s}$, no precipitation (fog, rain). In autumn, the time of the day was a restriction of the quadrocopter use in days with maximum low tides. The greatest low tides are shifted to the early morning hours in autumn. Hence, twilight did not allow us to use the quadrocopter for counting Kuril Seals.

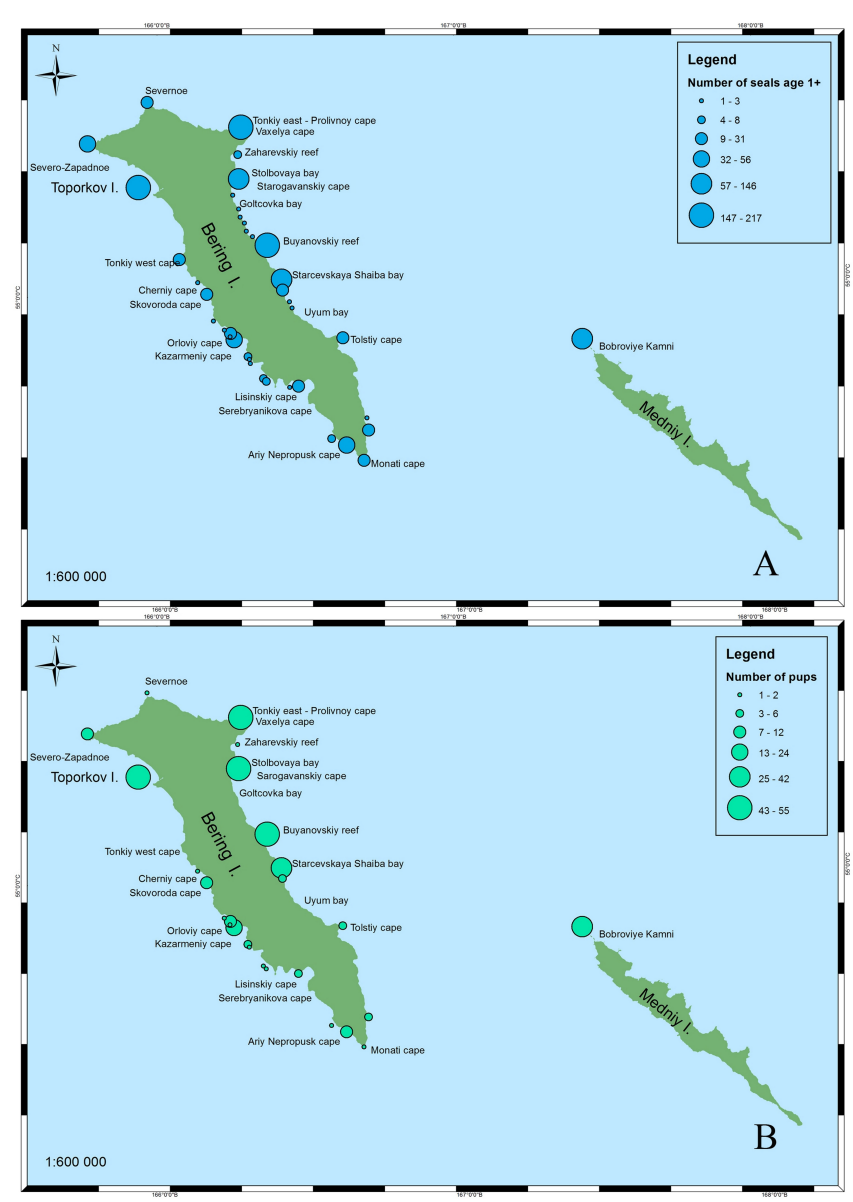

Fig. 1. The spatial arrangement of the rookeries of Phoca vitulina ssp. stejnegeri on Bering Island, Medniy Island and Toporkov Island. On Medniy Island, only site Bobroviye Kamni were examined. A - adult; B - pups.

All investigations have been carried out within a 4-hour period: two hours before the low tide and two hours after, in accordance with the behavioural features of Phoca vitulina ssp. stejnegeri on the rookeries (Thompson et al., 2005; Granquist \& Hauksson, 2016). However, due to a fairly long coastline, it was not always possible to be near the rookery at the necessary time. Nevertheless, $82.5 \%$ of the total number of surveys were performed within the established 4-hour window.

In total, 52 flights with a duration of $874 \mathrm{~min}$. and a length of $203.4 \mathrm{~km}$ were performed on Bering Island, three flights with a duration of $59 \mathrm{~min}$ utes and a length of $14.5 \mathrm{~km}$ - on Medniy Island, seven flights with a duration of $149 \mathrm{~min}$. and a length of $24.3 \mathrm{~km}$ - on Toporkov Island. A total of 6725 photographs were made.

\section{Results}

The number of Phoca vitulina ssp. stejnegeri on Bering Island and Toporkov Island. The entire coasts of Bering Island and Toporkov Island have been surveyed over the period from 25.06.2017 to 
10.07.2017. The total number of Phoca vitulina ssp. stejnegeri individuals was 1200 adults and 343 pups (Table 1 and Table 2).

The proportion of pups on the rookeries was similar for both islands, with an average of $22.2 \%$. The number of Kuril Seal individuals on Toporkov Island is $19.6 \%$ of the number on Bering Island.

Obtaining data on the number of any species is aimed to estimate the current state of a population for a long-term aspect. For this purpose, we attempted to analyse numerous data on the abundance of Phoca vitulina ssp. stejnegeri on the Commander Islands. Vaksel (1940) mentioned the first record of Kuril Seals on the Commander Islands. The author only briefly reported that «there is a great number of Kuril Seals» on the islands during the wintering of the Vitus Bering expedition in 1741/1742. Grebnitsky (1882) also pointed out that earlier there was a large number of the animals, but they were almost exterminated. The first quantitative data on the Phoca vitulina ssp. stejnegeri abundance can be found in BarabashNikiforov (1935). The author noted that on the site Bobroviye Kamni on Medniy Island, there were up to 100 or more individuals together, and only one rookery remained of the large number earlier. On the contrary, Sergeev (1938) reported that Kuril Seal formed several permanent rookeries on each of the islands. Ilyina (1950) made only the general estimation and noted that earlier from the Kuril Seals had been recorded a much larger number and that a part of their rookeries was emptied. Ilyina (1950) did not give data on the number of Phoca vitulina ssp. stejnegeri individuals, but provided information on the seal hunting.

Marakov (1962) provided the first data on the total number of Phoca vitulina ssp. stejnegeri individuals on the Commander Islands. The author estimated the number of the Kuril Seals at 1500 individuals on the islands in the early 1960s. It was suggested that a «noticeable increase» in the number of Phoca vitulina ssp. stejnegeri individuals on the islands (especially on Medniy Island) and the new rookeries formation took place from the $1950 \mathrm{~s}$ to the 1960s (Marakov, 1964, 1967). The total number of Phoca vitulina ssp. stejnegeri individuals was estimated by Marakov (1967) at 600 individuals on Bering Island. Marakov (1970) estimated the number of Kuril Seal individuals at 2000 individuals on the islands in the late 1960s. In the second half of the 1960s, Pinigin \& Pryanishnikov (1972) determined its number at 1394 individuals on Bering Island, and 703 individuals on Medniy Island.
In the 1970s the counting of Phoca vitulina ssp. stejnegeri on the Commander Islands began to be carried out more regularly by the staff of the Commander watch control station of the Kamchatka Basin Directorate for Fisheries, Conservation and Reproduction of Fish Resources. So, according to their investigations, the number of the Kuril Seals was 1414 individuals on the islands in 1973 (700 on Bering Island and 714 - on Medniy Island). At the same time, Marakov (1974) indicated that there were 2000 seals on the islands (1300 on Bering Island and 700 on Medniy Island), while Marakov (1978) noted the number of Phoca vitulina ssp. stejnegeri as 2500-2700 individuals, although it should be noted that the counting of Kuril Seals had not been carried out by exactly this author. In 1975 on the Commander Islands, according to Mymrin et al. (1979) the number of Phoca vitulina ssp. stejnegeri was 1612 individuals, while according to Goltsev \& Bukhtiyarov (1978) there were 2300 individuals. The largest number of the Kuril Seals on the islands was recorded in $1978-2816$ individuals (Annual report on the work, 1976-2004). In general, in the 1970s the estimated number of Kuril Seals varied from 1402 individuals (in 1977) to 2816 individuals (in 1978).

In the 1980s there was not any complete counting of the number of Kuril Seal individuals on the Commander Islands. Numerous countings have been carried out in some large areas, most often in the Severnoe and Severo-Zapadnoe rookeries. The total number of Phoca vitulina ssp. stejnegeri individuals was determined on the basis of the average long-term data and the results of surveys on the rookeries surveyed regularly (Annual report on the work, 1976-2004; Burdin et al., 1991). Thus, in this period there were only estimated data on the abundance of Kuril Seals. So, during this period the total number of Phoca vitulina ssp. stejnegeri was estimated at 2000-2500 individuals, including Bering Island (1500-2000 individuals) and Medniy Island (500-1000 individuals).

In the 1990s there was not any complete counting of the number of Kuril Seal individuals on the Commander Islands either, and data on its abundance were evaluative. Only in 1998 there was a complete survey of Medniy Island, where the total number of Phoca vitulina ssp. stejnegeri was 1224 individuals (Chronicle of Nature, 1995-2010; Zagrebelny \& Fomin, 2012). In general, in the 1990s the total number of Kuril Seals was estimated at 2200-3024 individuals on the Commander Islands, including Bering Island (1600-1800 individuals) and Medniy Island (600-1224 individuals). 
Table 1. The number of individuals of Phoca vitulina ssp. stejnegeri on Bering Island and Toporkov Island in 2017

\begin{tabular}{|c|l|c|c|}
\hline \multirow{2}{*}{ Data } & \multicolumn{1}{|c|}{ Studied coast } & \multicolumn{2}{|c|}{ Number } \\
\cline { 2 - 4 } & & adults & pups \\
\hline 25.06 .2017 & Bering Island. Severnoe and Severo-Zapadnoe rookeries & 75 & 9 \\
\hline 26.06 .2017 & Bering Island. From Goltsovka bay to Uyum bay & 348 & 93 \\
\hline 27.06 .2017 & Bering Island. Tonkiy west cape - Cherniy cape & 25 & 1 \\
\hline 29.06 .2017 & Bering Island. Severo-Zapadniy cape - Vaxelya ape & 167 & 55 \\
\hline 02.07 .2017 & Bering Island. Starogovanskiy cape, Stolbovaya bay & 199 & 48 \\
\hline 06.07 .2017 & Toporkov Island & 131 & 54 \\
\hline 08.07 .2017 & Bering Island. From Scovoroda cape to Lesinskiy cape & 104 & 57 \\
\hline 09.07 .2017 & Bering Island. From Tolstiy cape to Serebryanikova cape & 5 & 24 \\
\hline 10.07 .2017 & Bering Island. Zaharevskiy reef & & 2 \\
\hline
\end{tabular}

Table 2. The accounted number of Phoca vitulina ssp. stejnegeri individuals on Bering Island and Toporkov Island in 2017

\begin{tabular}{|l|c|c|c|c|}
\hline \multicolumn{1}{|c|}{ Island } & Adults & Pups & Total & Proportion of pups, \% \\
\hline Bering Island & 1001 & 289 & 1290 & 22.4 \\
\hline Toporkov Island & 199 & 54 & 253 & 21.3 \\
\hline Total & $\mathbf{1 2 0 0}$ & $\mathbf{3 4 3}$ & $\mathbf{1 5 4 3}$ & $\mathbf{2 2 . 2}$ \\
\hline
\end{tabular}

In 2005, a complete investigation of the number of Phoca vitulina ssp. stejnegeri was conducted on the Commander Islands. The total accounted number was 4128 individuals (Zagrebelny \& Fomin, 2012, 2014). In general, during this period estimates of the Phoca vitulina ssp. stejnegeri abundance were 3000-4128 individuals, including Bering Island (1900-2827 individuals) and Medniy Island (1000-1555 individuals) (Vyatkin \& Burkanov, 2006; Burdin et al., 2009; Zagrebelny \& Fomin, 2012, 2014; Chronicle of Nature, 1995-2010).

In the $2010 \mathrm{~s}$, the countings of the Phoca vitulina ssp. stejnegeri abundance on the Commander Islands were conducted several times. So, in 2012, a boat counting was taken only around Bering Island (Chronicle of Nature, 1995-2010; Zagrebelny \& Fomin, 2014) where the number of Kuril Seals was 2031 individuals. In 2015, a boat counting has been carried out together with investigations of Enhydra lutris Linnaeus, 1758. It resulted in estimating the number of Phoca vitulina ssp. stejnegeri at 1079 individuals on Bering Island (including Toporkov Island and Ariy Kamen Island), and 396 individuals - on Medniy Island (Differentiated Chronicle of Nature, 2016).

As countings has not been conducted on Medniy Island in 2017, we tried to determine the total number of the Kuril Seal on the islands using extrapolation method. According to the results of previous studies (Mymrin et al., 1979; Goltsev \& Bukhtiyarov, 1978; Burdin et al., 1991; Burkanov, 1988; Burdin et al., 2009; Annual report on the work, 1976-2004; Chronicle of Nature, 1995-2010, Zagrebelny \& Fomin, $2012,2014)$ the number of Phoca vitulina ssp. stejnegeri on Medniy Island is, on average, 2.24 times less than the total number of Kuril Seal individuals on Bering Island and Toporkov Island. Accordingly, in 2017, the total number of Phoca vitulina ssp. stejnegeri on Medniy Island are estimated at 689 individuals (i.e., 1543 / 2.24).

Thus, the number of Phoca vitulina ssp. stejnegeri on the Commander Islands is estimated at 2232 individuals, including 1543 individuals on Bering Island and Toporkov Island and 689 individuals on Medniy Island.

To calculate the total number of the seals, including those outside the rookery during low tide and thus not recorded, we used the formula $\mathrm{N}=2 \mathrm{n} /(0.521+0.698)$ suggested by Thompson et al. (1997). As a result, we get the total (absolute) number of Kuril Seals on the Commander Islands - 3344 individuals. As an assumption, we suggested that all newborn pups are on the rookeries and, accordingly, the calculation was made only on the basis of the number of adults plus the number of pups.

Based on the available data (Marakov, 1962, 1967, 1974; Goltsev \& Bukhtiyarov, 1978; Mymrin et al., 1979; Burkanov, 1988; Burdin et al., 1991; Vyatkin \& Burkanov, 2006; Zagrebelny \& Fomin, 2012, 2014; Annual report on the work, 1976-2004; Chronicle of Nature, 1995-2010; Differentiated Chronicle of Nature, 2016), we obtained a diagram for the dynamics of the Kuril Seals number on the Commander Islands (Fig. 2). 


\section{0}

2500

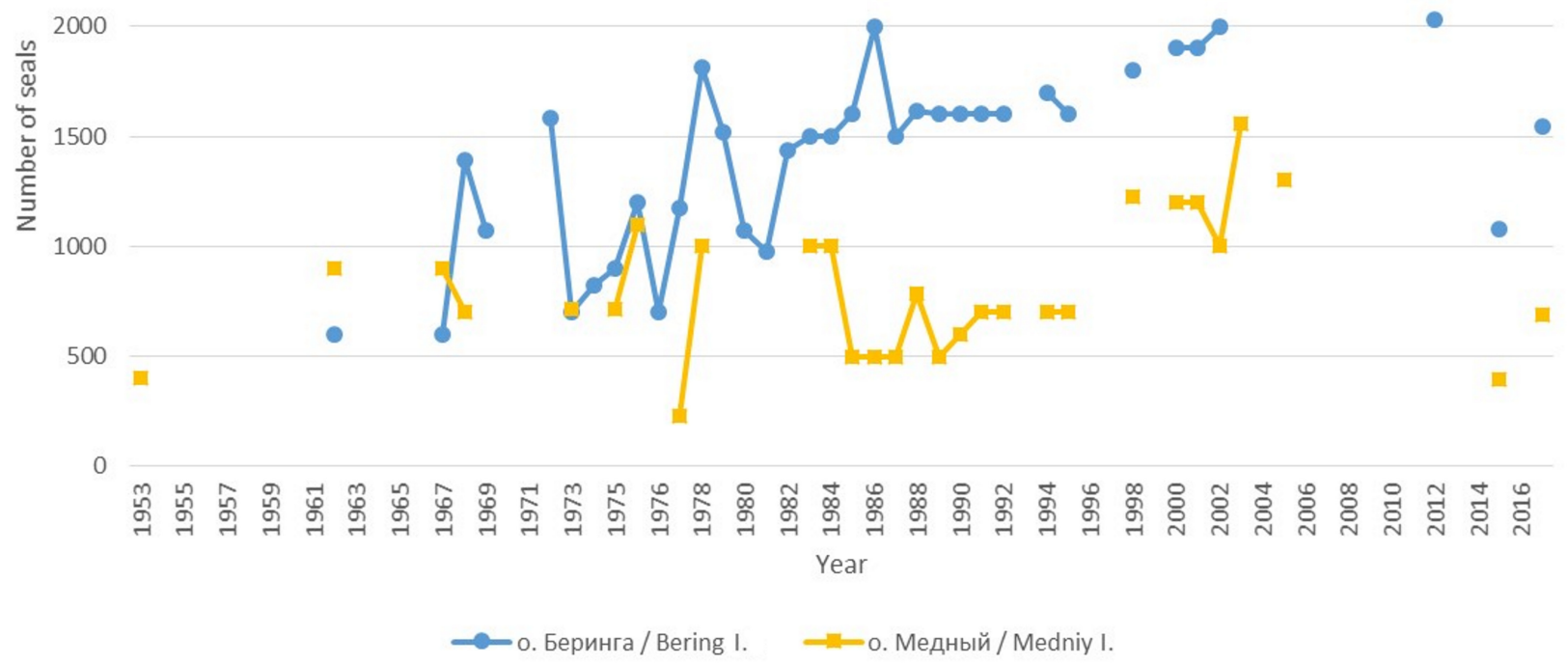

Fig. 2. Dynamics of the number of Phoca vitulina ssp. stejnegeri individuals on Bering Island (including Toporkov Island and Ariy Kamen Island) and Medniy Island, 1953-2017

Spatial distribution of the rookeries of Phoca vitulina ssp. stejnegeri. During the study period the entire coast of Bering Island and also Toporkov Island and Ariy Kamen Island have been investigated. In addition, the site Bobroviye Kamni on Medniy Island was examined twice. The collected material allowed us to estimate the spatial distribution of the rookeries of Phoca vitulina ssp. stejnegeri on the islands and to reveal the places, where the Kuril Seal forms the largest populations. One of the largest rookeries of Phoca vitulina ssp. stejnegeri is located on Toporkov Island during the breeding season (Fig. 1).

On the five largest rookeries, $69.2 \%$ of the total number of adult Phoca vitulina ssp. stejnegeri individuals is gathered on Bering Island and Toporkov Island (Table 3 ).

On Medniy Island the rookery was surveyed only at the northernmost tip of the island - site Bo- broviye Kamni. The number of animals at the age of $1+$ was 133 .

In addition to large rookeries of Phoca vitulina ssp. stejnegeri on Bering Island with populations containing more than 100 individuals, there were several sites with populations of several dozens of individuals. Among these are rookeries on SeveroZapadniy cape, Kazarmeniy cape, Ariy Nepropusk cape and Tolstiy cape.

Apart from the collective rookeries along the seacoast, there are also single seals resting on reefs. So, most records of single animals were registered along the eastern coast of Bering Island from Starogavanskiy cape to Uyum bay. In total, there were 20 single animals. They form only $1.7 \%$ of the total number of Phoca vitulina ssp. stejnegeri individuals. Thus, the main part of the Phoca vitulina ssp. stejnegeri population on Bering Island and Toporkov Island is gathered in large groups (Fig. 3).

Table 3. Distribution of Phoca vitulina ssp. stejnegeri along the rookeries on Bering Island and Toporkov Island

\begin{tabular}{|c|c|c|c|c|}
\hline \multirow{2}{*}{ Rookery } & \multicolumn{2}{|c|}{ Number of adults } & \multicolumn{2}{|c|}{ Number of pups } \\
\hline & $\mathrm{n}$ & $\%$ & $\mathrm{n}$ & $\%$ \\
\hline Toporkov Island & 199 & 16.6 & 54 & 15.7 \\
\hline Tonkiy cape - Prolivnoy cape & 167 & 13.9 & 55 & 16.0 \\
\hline Staragovanskiy cape & 146 & 12.2 & 48 & 14.0 \\
\hline Buyanovskiy reef & 217 & 18.0 & 50 & 14.6 \\
\hline Starcevskaya Shaiba bay & 102 & 8.5 & 40 & 11.7 \\
\hline All the rest & 369 & 30.8 & 96 & 28.0 \\
\hline Total & 1200 & 100 & 343 & 100 \\
\hline
\end{tabular}




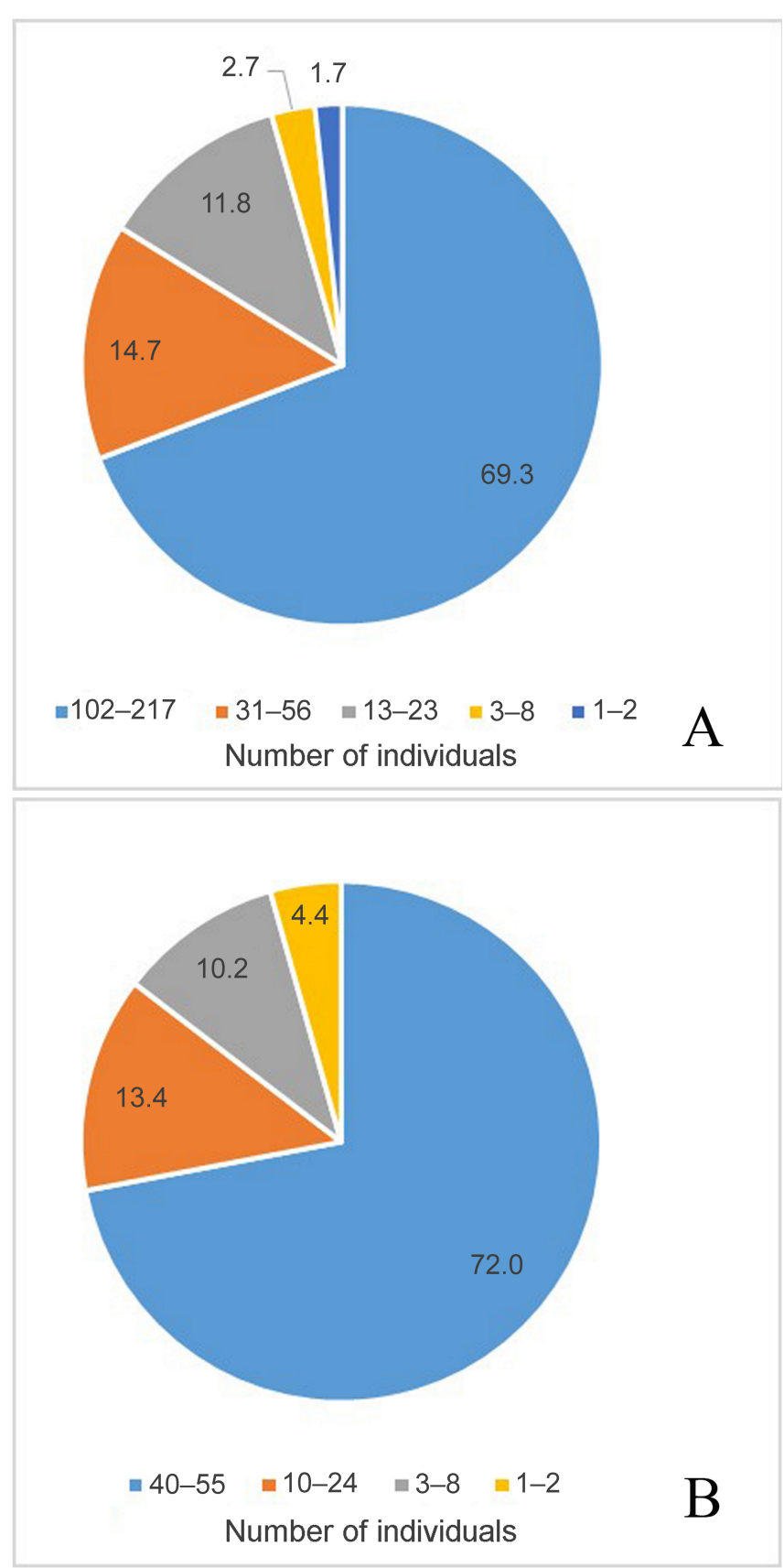

Fig. 3. Groups of Phoca vitulina ssp. stejnegeri ranked by number of individuals, \%. A - individuals aged $1+$ years, B - pups.

In addition to the counting of the animals aged $1+$ years, the pups were recorded. Data on the spatial distribution of pups are shown in Fig. 1. Similarly to adult animals, the majority of pups were in five large groups (Table 3).

Forty-two pups were registered at the site Bobroviye Kamni on Medniy Island. The total distribution of Kuril Seal pups is shown in Fig. 3 ranked by number of individuals. Thus, as can be seen in Fig. 3, the vast majority of pups of $72 \%$ was found in the large rookeries.

In the largest clusters, the birth rate of the $\mathrm{Ku}$ ril Seal varied from $18.7 \%$ (Buyanovskiy reef) to
$28.2 \%$ (reefs between Staraya Slastnaya bay and Startcevskaya Shaiba bay), with an average of $23.6 \%$. In general, the birth rate was $22.2 \%$ for all the rookeries of Bering Island and Toporkov Island.

Seasonal dynamics of the Kuril Seal population in the rookeries. During the summer - autumn period, Toporkov Island, reefs between Tonkiy east and Prolivnoy cape, Starogavanskiy cape, Buyanovskiy reef and Bobroviye Kamni were investigated repeatedly to determine the seasonal dynamics of the Kuril Seal population on the rookeries. The results of the survey are presented in Table 4.

There was a significant increase in the number of the seals in three rookeries, surveyed in the first two decades of August (Table 4). Later, a decline in the number of individuals was noted in three rookeries, while on Buyanovskiy reef the number of individuals continued to increase until the first decade of September. The number of Kuril Seal individuals has increased almost twice on site Bobroviye Kamni.

Comparison of the accuracy of various methods of Phoca vitulina ssp. stejnegeri counting. The accuracy of visual counting from a boat and from the coast was compared with the data obtained using the quadrocopter. The counting of Phoca vitulina ssp. stejnegeri has been carried out using the RIB boat, where the level of the eye height of an observer is approximately at 2.0-2.5 $\mathrm{m}$ above water level. The distance, from which the countings were carried out, differed slightly near the various reefs due to the peculiarities of the reef slabs location, depths near them, the location of the algal fields that did not allow them to approach closer, the behaviour of Phoca vitulina ssp. stejnegeri due to the wind direction. Data on results of the countings and observation distance are presented in Table 5.

The average accuracy of the visual counting of the seals is $67.7 \%$ (Table 5). At the same time, there is a significant variability in this accuracy from $29.7 \%$ to $76 \%$ and even rediscount on $19.4 \%$ (for example, on Tolstiy cape). The counting accuracy is highly depending on the relief and morphology of the reef itself, the characteristics of the animal location on a certain day, and the light conditions.

Comparative results of Kuril Seal pups counting from a boat are given in Table 6. It can be seen that during the visual counting on average $24 \%$ of pups are accounted from the boat with variations from $0 \%$ to $66.7 \%$. At the same time, there is not a regularity in the counting accuracy, depending on the counting distance. 
Table 4. Changes in the number of Phoca vitulina ssp. stejnegeri individuals on the rookeries

\begin{tabular}{|l|c|c|c|c|c|c|}
\hline \multicolumn{1}{|c|}{ Observation site } & $\begin{array}{c}\text { Number of } \\
\text { surveys }\end{array}$ & $\begin{array}{c}\text { Maximum number in the } \\
\text { breeding season (before } \\
10^{\text {th }} \text { July) }\end{array}$ & $\begin{array}{c}1^{\text {st decade }} \\
\text { of August }\end{array}$ & $\begin{array}{c}2^{\text {nd }} \text { decade } \\
\text { of August }\end{array}$ & $\begin{array}{c}3^{\text {rd }} \text { decade } \\
\text { of August }\end{array}$ & $\begin{array}{c}1^{\text {st }} \text { decade of } \\
\text { September }\end{array}$ \\
\hline Toporkov Island & 7 & 253 & no data & no data & 245 & no data \\
\hline Tonkiy east - Prolivnoy cape & 3 & 222 & no data & no data & 186 & no data \\
\hline Starogavanskiy cape & 10 & 194 & 373 & 271 & no data & 168 \\
\hline Buyanovskiy reef & 4 & 267 & no data & 325 & no data & 325 \\
\hline Bobroviye Kamni & 2 & 175 & no data & 344 & no data & no data \\
\hline
\end{tabular}

Table 5. The accuracy of visual counting of Phoca vitulina ssp. stejnegeri individuals at the age of $1+$ years obtained from the boat and drone

\begin{tabular}{|c|c|c|c|c|c|}
\hline \multirow[t]{2}{*}{ Data } & \multirow[t]{2}{*}{ Observation site } & \multirow{2}{*}{$\begin{array}{l}\text { Distance of counting } \\
\text { with binoculars, } m\end{array}$} & \multicolumn{2}{|c|}{$\begin{array}{c}\text { Number of Phoca vitulina } \\
\text { ssp. stejnegeri }\end{array}$} & \multirow{2}{*}{$\begin{array}{l}\text { Value of visual counting in comparison } \\
\text { with the record with drone, } \%\end{array}$} \\
\hline & & & from boat & using drone & \\
\hline 12.06 .2017 & Toporkov Island & 140 & 88 & 184 & 47.8 \\
\hline 06.07 .2017 & Toporkov Island & 140 & 152 & 199 & 76.4 \\
\hline 29.06.2017 & Tonkiy cape - Prolivnoy cape & 360 & 72 & 167 & 43.1 \\
\hline 08.07 .2017 & Skovoroda cape & 730 & 24 & 22 & 109.1 \\
\hline 08.07 .2017 & Orloviy cape & 350 & 10 & 15 & 66.7 \\
\hline 08.07 .2017 & Kazarmeniy cape & 460 & 35 & 52 & 67.3 \\
\hline 08.07 .2017 & Lisinskiy cape & 449 & 7 & 14 & 50.0 \\
\hline 09.07 .2017 & Tolstiy cape & 490 & 37 & 31 & 119.4 \\
\hline \multirow[t]{2}{*}{09.07 .2017} & Ariy Nepropusk cape & 305 & 11 & 37 & 29.7 \\
\hline & Average & 380 & & & 67.7 \\
\hline
\end{tabular}

A visual coastal counting of Phoca vitulina ssp. stejnegeri, aimed to determine the accuracy of the counting methods, has been carried out on several places where the largest seal groups are located. The distance from the observation place to the rookeries was different. It was $347-419 \mathrm{~m}$ in Startsevskaya Shaiba bay, $425 \mathrm{~m}$ in Stolbovaya bay, $842 \mathrm{~m}$ on Starogavanskiy cape, 519-904 m on Buyanovskiy reef, $715 \mathrm{~m}$ on Tonkiy west cape. This distance was longer during observation from the slope. So, the distance from the observation point to the rookeries was $344 \mathrm{~m}$ on Tonkiy east - Prolivnoiy cape, $1072 \mathrm{~m}$ on Starogavanskiy cape, 866-1245 m on Buyanovskiy reef.

A visual coastal counting has been carried out both from a height of $2-3 \mathrm{~m}$ (at the first coastal terrace) and from slopes at a height of at least $17 \mathrm{~m}$. Table 7 presents data on the accuracy of the visual counting of Kuril Seals from a height of 2-3 $\mathrm{m}$ without dividing the animals into age groups.

As can be seen from Table 7, an average of $39.6 \%$ of Kuril Seal individuals can be counted on the rookeries using binoculars from the coast. A comparable accuracy level was obtained by using a telescope.
Table 8 presents data on the accuracy of the visual counting of Phoca vitulina ssp. stejnegeri individuals, being obtained from a height of at least $17 \mathrm{~m}$. The accuracy of the visual counting increases in case of observation from slopes. And, on average, it is $62 \%$ in case of observation using binoculars. A similar accuracy level was obtained by observation using a telescope.

\section{Discussion}

The abundance of Phoca vitulina ssp. stejnegeri. Despite of the obtained data on dynamics in Fig. 1, we should note that the curve of the number of Phoca vitulina ssp. stejnegeri does not reflect adequately the right situation with the dynamics of the Kuril Seal number on the Commander Islands due to some reasons:

- Sometimes data on the number of Phoca vitulina ssp. stejnegeri individuals on the islands have not been determined as a result of direct countings. Usually the number of individuals has been estimated on the basis of certain generalisation using the maximum values for separate rookeries.

- To count the number of Kuril Seals, data obtained in different seasons of the year and, accordingly, various annual life cycles of the animal were used. 
Table 6. The accuracy of the visual counting of Phoca vitulina ssp. stejnegeri pups obtained from the boat and drone

\begin{tabular}{|c|c|c|c|c|c|}
\hline \multirow[t]{2}{*}{ Date } & \multirow[t]{2}{*}{ Observation site } & \multirow{2}{*}{$\begin{array}{c}\text { Distance of } \\
\text { counting with } \\
\text { binoculars, m }\end{array}$} & \multicolumn{2}{|c|}{$\begin{array}{c}\text { Number of Phoca vitulina ssp. } \\
\text { stejnegeri }\end{array}$} & \multirow{2}{*}{$\begin{array}{l}\text { Value of visual counting in comparison } \\
\text { with the record with drone, } \%\end{array}$} \\
\hline & & & from boat & with drone & \\
\hline 12.06 .2017 & Toporkov Island & 140 & 0 & 25 & 0.0 \\
\hline 06.07 .2017 & Toporkov Island & 140 & 17 & 54 & 31.5 \\
\hline 29.06 .2017 & Tonkiy cape - Prolivnoy cape & 360 & 5 & 55 & 9.1 \\
\hline 08.07.2017 & Skovoroda cape & 730 & 0 & 8 & 0.0 \\
\hline 08.07 .2017 & Orloviy cape & 350 & 5 & 10 & 50.0 \\
\hline 08.07 .2017 & Kazarmeniy cape & 460 & 2 & 24 & 8.3 \\
\hline 08.07 .2017 & Lisinskiy cape & 449 & 2 & 3 & 66.7 \\
\hline 09.07 .2017 & Tolstiy cape & 490 & 2 & 6 & 33.3 \\
\hline \multirow[t]{2}{*}{ 09.07.2017 } & Ariy Nepropusk cape & 305 & 2 & 12 & 16.7 \\
\hline & Average & 380 & & & 24.0 \\
\hline
\end{tabular}

Table 7. The accuracy of the visual counting of Phoca vitulina ssp. stejnegeri of all age groups from a height of 2-3 $\mathrm{m}$

\begin{tabular}{|c|l|c|c|c|c|c|}
\hline \multirow{2}{*}{ Date } & \multirow{2}{*}{ Observation site } & \multicolumn{3}{|c|}{ Number } & \multicolumn{2}{c|}{$\begin{array}{c}\text { Value of visual counting in comparison } \\
\text { with the record with drone, } \%\end{array}$} \\
\cline { 3 - 7 } & & binoculars & telescope & drone & binoculars & telescope \\
\hline 26.06 .2017 & Starcevskaya Shaiba bay & 35 & - & 142 & 24.6 & - \\
\hline 10.07 .2017 & Stolbovaya bay & 37 & - & 49 & 75.5 & - \\
\hline 20.09 .2017 & Stolbovaya bay & 26 & - & 67 & 38.8 & - \\
\hline 26.06 .2017 & Buyanovskiy reef & 162 & - & 267 & 60.7 & 52.6 \\
\hline 20.08 .2017 & Buyanovskiy reef & 124 & 171 & 325 & 38.2 & - \\
\hline 07.09 .2017 & Buyanovskiy reef & 138 & - & 353 & 39.1 & - \\
\hline 22.09 .2017 & Buyanovskiy reef & 74 & - & 181 & 40.9 & - \\
\hline 10.07 .2017 & Zaharevskiy reef & 4 & - & 7 & 57.1 & 29.2 \\
\hline 18.06 .2017 & Starogavanskiy cape & 24 & 33 & 113 & 21.2 & - \\
\hline 10.07 .2017 & Starogavanskiy cape & 38 & - & 165 & 23.0 & 15.1 \\
\hline 10.08 .2017 & Starogavanskiy cape & 50 & 50 & 331 & 15.1 & 24.6 \\
\hline 20.08 .2017 & Starogavanskiy cape & 57 & 48 & 195 & 29.2 & - \\
\hline 20.09 .2017 & Starogavanskiy cape & 25 & - & 92 & 27.2 & \\
\hline 27.06 .2017 & Tonkiy west cape & 15 & 17 & 23 & 65.2 & \\
\hline 25.08 .2017 & Tonkiy west cape & 9 & - & 20 & 45.0 & \\
\hline 27.06 .2017 & Cherniy cape & 1 & - & 3 & 33.3 & \\
\hline & Average & & & & $\mathbf{3 9 . 6}$ & - \\
\hline
\end{tabular}

Table 8. The accuracy of the visual counting of Phoca vitulina ssp. stejnegeri of all age groups from a height of at least $17 \mathrm{~m}$

\begin{tabular}{|c|l|c|c|c|c|c|}
\hline \multirow{2}{*}{ Date } & \multicolumn{2}{|c|}{ Observation site } & \multicolumn{3}{|c|}{ Number } & \multicolumn{2}{c|}{$\begin{array}{c}\text { Value of visual counting in comparison with } \\
\text { the record with drone, } \%\end{array}$} \\
\cline { 3 - 7 } & & binoculars & telescope & drone & binoculars & telescope \\
\hline 07.09 .2017 & Buyanovskiy reef & 137 & 160 & 297 & 46.1 & 53.9 \\
\hline 22.09 .2017 & Buyanovskiy reef & 74 & 101 & 175 & 42.3 & 57.7 \\
\hline 18.06 .2017 & Starogavanskiy cape & 42 & 54 & 96 & 43.8 & 56.3 \\
\hline 02.07 .2017 & Starogavanskiy cape & - & 51 & 51 & - & 100.0 \\
\hline 10.07 .2017 & Starogavanskiy cape & 78 & 87 & 165 & 47.3 & 52.7 \\
\hline 10.08 .2017 & Starogavanskiy cape & 117 & 194 & 311 & 37.6 & 62.4 \\
\hline 20.08 .2017 & Starogavanskiy cape & 73 & 101 & 174 & 42.0 & 58.0 \\
\hline 24.08 .2017 & Tonkiy cape - Prolivnoy cape & 208 & - & 208 & 100.0 & - \\
\hline 23.09 .2017 & Tonkiy cape - Prolivnoy cape & 90 & - & 90 & 100.0 & - \\
\hline 25.06 .2017 & Severnoe & 12 & 16 & 28 & 42.9 & \\
\hline 25.06 .2017 & Severo-Zapadnoe & 12 & - & 12 & 100.0 & 57.1 \\
\hline 25.06 .2017 & Severo-Zapadnoe & 27 & 37 & 64 & 42.2 & - \\
\hline 18.09 .2017 & Severo-Zapadnoe & 12 & - & 12 & 100.0 & \\
\hline & Average & & & & $\mathbf{6 2 . 0}$ & 57.8 \\
\hline
\end{tabular}


In addition, we should take into account significant fluctuations of the number of individuals in some years. For example, in 1967, the number of Phoca vitulina ssp. stejnegeri was estimated at 600 individuals on Bering Island (Marakov, 1967), while in the next year it was 1394 individuals at the same location (Pinigin \& Pryanishnikov, 1972). Thus, the value has increased on $132.3 \%$. Similar fluctuations could be found in other years. For example, in 2002, the number of Kuril Seals was estimated at 2000 individuals on Bering Island, while in 2005 it was 2827 individuals (Chronicle of Nature, 1995-2010; Zagrebelny \& Fomin, 2012, 2014 ), i.e. the growth was $41.4 \%$. It is obvious, that such an abundance growth of the resident animal is not possible. This is confirmed by results of other authors for closely related animals. For example, the annual increase of the seal number in the Phoca vitulina population in Wash (England) after a severe post-epidemic reduction was only $6 \%$, in the population of the seal in the southeastern part of the North Sea it was $8.8-12.7 \%$, and in the population in Kattegat-Skagerrak it was 12\% (Thompson et al., 2005). In most parts of the range, the growth of the Phoca vitulina number is $12-13 \%$ per year (Harkonen et al., 2002). At the same time, the death rate of pups is high enough at the end of breastfeeding. For example, in Canada it is 12 $21 \%$ (Hammill et al., 2010), while the mortality value for pups before six months is up to $43 \%$. Estimates of the number of Kuril Seals differed even within one year enormously. For example, in 1975 the difference in the number was 688 individuals according to the data of different researchers (Goltsev \& Bukhtiyarov, 1978 vs. Mymrin et al., 1979). In our opinion, high fluctuations of the number of Phoca vitulina ssp. stejnegeri individuals can be explained by the methodological imperfection of the conduced surveys, but not the real values of dynamics in animal abundance.

In addition, it should be noted that, probably, although not obviously, previous researchers, by estimating the total number of Phoca vitulina ssp. stejnegeri on the Commander Islands, had in mind the exactly total number of Kuril Seals, but not only the accounted one. This assumption is based on the fact that during the breeding season, only a part of the seal population is located on a rookery. And according to some studies, from $52.1 \%$ of males to $69.8 \%$ of females are located on the rookery during the breeding season (Thompson et al., 1997). And during moulting, the total number of seals will be higher with an average of $37 \%$
(Sharples et al., 2009). Consequently, the total (absolute) number of the seals will be higher than the accounted number.

Based on all the aspects discussed above, related to the available data on the animal abundance, to obtain an adequate picture on the dynamics of the Kuril Seal number, an additional generalisation and analysing of the available materials are required. Before this, there is no way to discuss an objective picture of dynamics of the Kuril Seal number on the Commander Islands.

The features of the reproduction of Phoca vitulina ssp. stejnegeri on the Commander Islands. In addition to data on the number of Phoca vitulina ssp. stejnegeri individuals on the Commander Islands, information on breeding has also been taken into account during previous decades. However, these data are extremely limited. In particular, Marakov $(1964,1967)$ noted that the pup birth occurred until late June. Vyatkin \& Burkanov (2006) gave information that Phoca vitulina ssp. stejnegeri bred in late May - June. Burdin et al. (1991) pointed out that on the Commander Islands, the breeding peak of the Kuril Seal was in the first decade of June. There are not published data on the number of Phoca vitulina ssp. stejnegeri pups on the Commander Islands.

As a result of the study, we first obtained data on the number of Kuril Seal pups for Bering Island and Toporkov Island. We attempted to count the absolute and specific birth rate of pups on the Commander Islands. Thus, we made two assumptions: 1) all newborn pups are on the rookeries, i.e. the accounted number of pups is close to the value of their absolute number in a location; 2) the ratio of the number of pups on Bering Island and Toporkov Island to the number of pups on Medniy Island is 2.24 , i.e. the value that we used to calculate the total number of Kuril Seals. Then we have 343 pups on Bering Island and Toporkov Island and 153 pups on Medniy Island. As a result, the absolute birth rate will be 496 pups for the Commander Islands. Using the accounted absolute number of animals beyond one-year-old (2848 individuals), we get a specific birth rate $-17.4 \%$. According to some data (Reijnders, 1982), a normal birth rate of Phoca vitulina populations is $20-30 \%$.

There are two rookeries (Toporkov Island and Starogavanskiy cape on the east coast of Bering Island), where massive bedding and breeding of Kuril Seals are observed. These locations were examined twice during the reproductive period. During the survey of Toporkov Island, 25 pups were 
found on $12^{\text {th }}$ June, and 54 pups were found on $6^{\text {th }}$ July. Thus, 29 pups were born during 24 days here. This is $53.7 \%$ of the total number of pups born. On Starogavanskiy cape there were 28 pups on $18^{\text {th }}$ June, and 48 pups on $2^{\text {nd }}$ July. Thus, the number of pups increased by $45.8 \%$. According to these data, mass breeding of Phoca vitulina ssp. stejnegeri on the Commander Islands occurs in the second half of June, but this issue needs to be clarified.

Probably, individual pups can be born also after the end of the mass breeding. For example, a newborn pup of Phoca vitulina ssp. stejnegeri was recorded on Buyanovskiy reef on $20^{\text {th }}$ August. And another survey of the rookery ( $7^{\text {th }}$ September) found out one pup kept contact with the mother. Before our study, the latest case of the birth of the Kuril Seal pup was noted on Toporkov Island on $17^{\text {th }}$ July, 1990 (Annual report on the work, 1976-2004). Thus, the breeding period of Phoca vitulina ssp. stejnegeri on the Commander Islands is fairly extended - from May to August. But the main part of pups are born probably in the second half of June.

Spatial distribution. The collected material makes it possible to estimate the spatial distribution of the Kuril Seal rookeries. The main large clusters were found on Toporkov Island, on Tonkiy east-Prolivnoy cape, on Starogavanskiy cape, on Buyanovskiy reef, in Startsevskaya Shaiba bay.

In the 1960s on the coast of Bering Island the largest cluster of Phoca vitulina ssp. stejnegeri was recorded in Kazarma bay with up to 200 individuals (Marakov, 1967). In comparison with the results of studies in 2005 (Zagrebelny \& Fomin, 2012, 2014), in 2017 there was no large group of animals in the Severo-Zapadnoe rookery. But the number of the seals increased on Starogavanskiy cape. However, it should be noted that the counting has been carried out in late July 2005, i.e. at the beginning of the moulting, when the Kuril Seal number on the rookeries is believed to increase. In addition, the number of Phoca vitulina ssp. stejnegeri on some rookeries can significantly fluctuate within a month and during several days (Nikulin \& Nikulin, 2012; our data). In this connection, it is difficult to draw unequivocal conclusions on the changes in the spatial distribution of Phoca vitulina ssp. stejnegeri groups along the rookeries. Nevertheless, the general features of the arrangement of the most significant sites of the Phoca vitulina ssp. stejnegeri concentration remain. On Medniy Island, the largest (from 100 to 300 individuals) rookery of Phoca vitulina ssp. stejnegeri was found on Bobroviye Kamni site like in all previous years since the 1930s. (Barabash-
Nikiforov, 1935; Marakov, 1967). Thus, in general, there are some remaining peculiarities of the spatial distribution of Kuril Seals, but there are also differences. This issue requires a more detailed elaboration in the future.

Seasonal dynamics of the Kuril Seal number. As a result of the work carried out, seasonal changes (from June to October) in the Phoca vitulina ssp. stejnegeri number on some rookeries have been revealed. The growth of the seal number during the seasonal moult, which occurs in August, was recorded on all the rookeries that could be inspected in the first half of August. And the number of Kuril Seals continued to grow on the distinct rookeries in September. It is difficult to draw conclusions at the expense why the number increases. It is believed that the increase in the number is a consequence of the fact that a larger number of the seals are present at the rookeries. But it is also possible there is some redistribution of the seals between the rookeries. Thus, the decrease in the Phoca vitulina ssp. stejnegeri number on Starogavanskiy cape in September and the increase of its number on Buyanovskiy reef can be attributed to the spatial redistribution of animals along the eastern coast of Bering Island. However, additional research is required for an unambiguous approval.

Comparison of the counting methods accuracy. Despite the fact that Phoca vitulina ssp. stejnegeri is a permanent inhabitant of the coastal waters on the Commander Islands, detailed studies of its ecology have not been conducted. Even the estimate of the total number was carried out for the first time only in the 1950 s. In general, two counting methods of the Kuril Seal number have been used on the Commander Islands - from the shore (coastal counting) and from a boat (boat counting).

Unfortunately, there is no description of the methods used by Marakov (1962, 1967, 1974) for counting the animal number. So, it is not clear whether the author counted Phoca vitulina ssp. stejnegeri from the shore or from the boat. We do not know either how often such countings were made, in which seasons, which rookeries and how many times during the year. Taking into account the round values of the seal number in Marakov's $(1962,1967,1974)$ data, it can be assumed that the author did not give any accounted data. But the author provided an estimated intuitive number of Phoca vitulina ssp. stejnegeri on the islands.

The first data of the accounted number of the Kuril Seals are given by Pinigin \& Pryanishnikov (1972). However, the authors counted the seals on 
Bering Island in February, and on Medniy Island in June, 1968. Thus, the data obtained in different seasons cannot be compared with the results of the surveys performed during the breeding season of Phoca vitulina ssp. stejnegeri. In addition, it is not clear how many rookery surveys were performed on Bering Island in February and what data on the number of animals were used for the publication the maximum for several records or average values. There is no information on the counting method of Phoca vitulina ssp. stejnegeri on Medniy Island. Further estimates of the Kuril Seal number on the islands were made on the basis of the average longterm data on the individual rookeries (Burdin et al., 1991). Thus, for the entire period of the counting, we do not have accurate data on the Phoca vitulina ssp. stejnegeri number on the Commander Islands. The exception is data (sometimes long time series) obtained on distinct places of the rookeries. But in publications or reports there is no detailed description of the methods of counting. The only description of the method of boat counting can be found in Zagrebelny \& Fomin $(2012,2014)$.

To clarify the methodological features of coastal countings, we requested N.I. Mymrin and V.S. Nikulin, who worked in the Commander watch control station of the Kamchatka Basin Directorate for Fisheries, Conservation and Reproduction of Fish Resources in 1970-1990s. And they were engaged in counting of Phoca vitulina ssp. stejnegeri. So, according to the oral report of N.I. Mymrin, who has carried out countings in the 1970s, the study of Phoca vitulina ssp. stejnegeri on the rookeries along the eastern coast of Bering Island was led from the first coastal terrace with the use of 7-fold binoculars. In 1980-1990s the counting of Kuril Seals has been carried out from the coastal line using 8-10-fold binoculars (V.S. Nikulin, personal communication). To carry out countings in the Severnoe and SeveroZapadnoe rookeries, a telescope 30-60 was used. Extrapolations were not used. According to the oral report of E.S. Baldin, who conducted countings in the 2000s, the studies along the eastern coast of Bering Island were also performed from the first coastal terrace or from the road. Occasionally, the inspection of Starogavanskiy cape was made from a 10 $\mathrm{m}$ coastal cliff. In this survey, $8-10$-fold binoculars were used. Only the directly counted seal number was recorded in the diary of observations, i.e. without extrapolation to the invisible hidden part.

One of our tasks was to establish the accuracy of the visual counting in comparison with the counting with photographs taken from the quadro- copter. As already mentioned, the most accurate data on the number of Phoca vitulina on the rookeries can be obtained only during aerophotography (Thompson \& Harwood, 1990; Cronin et al., 2004). So, we found out that during the boat counting the observer can record on average only $67.7 \%$ of adult animals and $24 \%$ of pups. During coastal countings, on average, the observer can register only $39.6 \%$ of Kuril Seals of all age groups, if the observation is taken from the first coastal terrace, similarly to studies of previous years. In other parts of the Phoca vitulina range, the accuracy of the visual counting in comparison with aerocounting averaged $73 \%$ and depended on the number of the seals: the accuracy decreased with increasing of the number of seals (Thompson \& Harwood, 1990).

However, even if we know the level of undercounting by using the traditional visual counting of Kuril Seal, it is difficult to apply the correction factor to the data obtained in this way. This is connected with the individual error of the accountant: so, the accountant can both underestimate the seals and overestimate their number. In addition, the error of the visual counting for the same accountant varies depending on the pecularities of arrangement of the seals on a rookery at different times. For example, the animals may be arranged more open and dispersed, or may also move over the protruding ridges and stones on the reefs and lie densely. Also, the lighting conditions, distance and other factors also impact on the counting accuracy. For example, in Zagrebelny \& Fomin $(2012,2014)$ the authors noted that the counting was made at a considerable distance from the rookeries and in conditions of limited time, i.e. the rookeries were inspected for a short time. In such conditions it is extremely difficult to determine the correction factor for obtaining updated data on the number of Kuril Seals. Nevertheless, the obtained data allow us, to some extent, to correct the values of the countings performed in previous years by using the visual method.

\section{Conclusions}

For the first time, Phoca vitulina ssp. stejnegeri was counted using aerophotography on the Commander Islands. This method gives the most objective data on the number of animals. Data obtained using an unmanned aerial vehicle on the current number of Kuril Seals do not allow us to estimate the long-term dynamics of its number on the islands. This is due to the fact that since the 1950s, all studies of the Kuril Seal number have been performed by using the visual method. And 
the general estimates of its number on the islands were most often given rather on the basis of some expert estimates, than calculations. In order to include the whole data on the Phoca vitulina ssp. stejnegeri number on the Commander Islands in assessment of the historical dynamics of its abundance, it is first necessary to conduct a thorough analysis of the counting data. Such analysis should include both an estimate of the Kuril Seal number on each particular rookery, and its dynamics during the season and between years.

To determine the absolute number of Phoca vitulina ssp. stejnegeri on the Commander Islands, we made assumptions about the level of the Kuril Seal number on the rookeries at low tide, based on available literature from other parts of its range. However, the local populations of the animal may have its own specific features. To clarify this issue, it is required to tag the animals. Labelling combined with using satellite transmitters will also make it possible to assess the nature of the water area use on the islands by Phoca vitulina ssp. stejnegeri, and the degree of their confinement to specific rookeries, and many other aspects.

Also, for the first time, data on the number of pups on the Commander Islands were obtained. The reproduction level was close to that in other parts of the Phoca vitulina range. Simultaneously, the continuation of such studies is required in order to exclude possible interannual fluctuations and counting errors.

The study showed that Phoca vitulina ssp. stejnegeri uses traditionally the coasts of the Commander Islands. So, the largest rookeries are located in the same places where they were known during the previous decades. Such a traditional arrangement of the coast by the animal can be used for rapid assessment of its number on the rookeries, by surveying only the largest rookeries, taking into account what proportion they occupy of the total number of Kuril Seals.

The seasonal dynamics of the Kuril Seal number has not been adequately studied. Nevertheless, it has been shown that during the seasonal moult, the number of the seals increases on the rookeries. Although, this does not happen everywhere. Therefore, research on this topic should be continued in future.

An important result of our study was the assessment of the accuracy of the visual counting method, traditionally used on the Commander Islands. A correction factor was obtained for the Kuril Seal counting. Taking into account certain limitations, it can be used to adjust or discuss the available historical data.
In general, taking into account the biological pecularities of the Kuril Seal, it can be concluded that Phoca vitulina ssp. stejnegeri is a complex object for research and estimation of its abundance. Undoubtedly, one season studies are not enough to draw serious conclusions about the state of its population.

\section{Acknowledgements}

The author is cordially grateful to A.V. Kuznetsova and E.I. Chekalsky for the help in the collection of the primary field material, and also thanks N.I. Mymrin, V.S. Nikulin and E.S. Baldin for additional information on the counting methods of Phoca vitulina on the Commander Islands in the past.

\section{References}

Annual report on the work on the Commander Islands. Nikolskoe: The Commander Islands observation point of the Kamchatka Basin Directorate for Fisheries, Conservation and Reproduction of Fish Resources, 1976-2004. [In Russian]

Barabash-Nikiforov I.I. 1935. Pinnipeds of the Commander Islands. Trudy VNIRO 3: 223-237. [In Russian]

Bjørge A., Øien N., Fagerheim K.-A. 2007. Abundance of Harbour Seals (Phoca vitulina) in Norway Based on Aerial Surveys and Photographic Documentation of Hauled-Out Seals During the Moulting Season, 1996 to 1999. Aquatic Mammals 33(3): 269-275. DOI: 10.1578/AM.33.3.2007.269

Brasseur S., Creuwels J., Werf B., Reijnders R. 1996. Deprivation indicates necessity for haul-out in harbour seals. Marine Mammal Science 12(4): 619-624. DOI: 10.1111/j.1748-7692.1996.tb00077.x

Burdin A.M., Vertyankin V.V., Nikulin V.S, Fomin V.V. 1991. Modern state of earless seals population on the Commander Islands. In: Proceedings on marine mammals of the northern part of Pacific Ocean in 1989-1990. Moscow: Russian Federal Research Institute of Fisheries and Oceanography. P. 82-94. [In Russian]

Burdin A.M., Filatova O.A., Hoyt E. 2009. Marine mammals of Russia: field guide. Kirov: Volga-Vyatka Publishing House. 210 p. [In Russian]

Burkanov V.N. 1988. Modern state of marine mammals resources on Kamchatka. In: Rational use of Kamchatka shelf bioresources. Petropavlovsk-Kamchatsky: Far East Publishing House, Kamchatka office. P. 138-176. [In Russian]

Chronicle of Nature of the Commander Islands State Nature Biosphere Reserve. Nikolskoe, 1995-2010. [In Russian]

Cronin M., Duck C., Ó Cadhla O., Nairn R., Strong D., O'Keeffe C. 2004. Harbour seal population assessment in the Republic of Ireland: August 2003. Irish Wildlife Manuals. Vol. 11. Dublin, Ireland: National Parks \& Wildlife Service, Department of Environment, Heritage and Local Governement. 39 p.

Differentiated Chronicle of Nature of the Commander Islands State Nature Biosphere Reserve, 2015. Vol. 4. Nikolskoe, 2016. [In Russian]

Goltsev V.N., Bukhtiyarov Yu.A. 1978. Additions to the morpho-ecological characteristics of harbors seals on the 
Commander Islands. In: Marine mammals: Abstracts of All-Union Seventh Meeting(Simferopol, 20-23 September, 1978). Simferopol. P. 90-91. [In Russian]

Granquist S.M., Hauksson E. 2016. Seasonal, meteorological, tidal and diurnal effects on haul-out patterns of harbor seals (Phoca vitulina) in Iceland. Polar Biology 39(12): 2347-2359. DOI: 10.1007/s00300-016-1904-3

Grebnitsky N.A. 1882. Note on the Commander Islands. In: Collection of the Main Official Documents for Eastern Siberia Government. Vol. 3: Kamchatka and the Commander Islands. Vol. 2: The Commander Islands. Irkutsk: N.N. Sinitsin Publishing House. P. 42-125. [In Russian]

Grellier K., Thompson P.M., Corpe H.M. 1996. The effect of weather condition on harbour seal (Phoca vitulina) haulout behaviour in the Morey Firth, northeast Scotland. Canadian Journal of Zoology 74(10): 1806-1811. DOI: $10.1139 / \mathrm{z} 96-201$

Hammill M.O., Bowen W.D., Sjare B. 2010. Status of harbour seals (Phoca vitulina) in Atlantic Canada. NAMMCO Scientific Publications 8: 175-190. DOI: $10.7557 / 3.2684$

Harkonen T., Harding K.C., Heide-Jorgensen M.-P. 2002. Rates of increase in age-structured populations: a lesson from the European harbour seals. Canadian Journal of Zoology 80(9): 1498-1510. DOI: 10.1139/Z02-141

Harvey G.T., Goley D. 2011. Determining a correction factor for aerial surveys of harbor seals in California. Marine Mammal Science 27(4): 719-735. DOI: 10.1111/j.17487692.2010.00446.x

Ilyina E.D. 1950. Insular Animal Breeding. Moscow: Mezhdunarodnaya Kniga. 302 p. [In Russian]

London J.M., Ver Hoef J.M., Jeffries S.J., Lance M.M., Boveng P.L. 2012. Haul-Out Behavior of Harbor Seals (Phoca vitulina) in Hood Canal, Washington. PLoS ONE 7(6): e38180. DOI: 10.1371/journal.pone.0038180

Lowry L. 2016. Phoca vitulina. In: The IUCN Red List of Threatened Species 2016: e.T17013A45229114. Available from: http://dx.doi.org/10.2305/IUCN.UK.2016-1. RLTS.T17013A45229114.en

Marakov S.V. 1962. Modern state of mammals and birds fauna on the Commander Islands. Bulletin of Moscow Society of Naturalists. Biological Series 67(2): 143-144. [In Russian]

Marakov S.V. 1964. Mammals and birds of the Commander Islands (ecology and practical use). PhD Thesis. Moscow. 360 p. [In Russian]

Marakov S.V. 1967. Materials on Spotted Seal ecology on the Commander Islands. In: Proceedings of the Polar Research Institute of Marine Fisheries and Oceanography 21: 126-136. [In Russian]

Marakov S.V. 1970. Main hunting areas of the North Pacific Region and ways to increase their productivity. In: Proceedings of the IX International Congress of Biologists - game managers (Moscow, September 1969). Moscow. P. 781-784. [In Russian]

Marakov S.V. 1974. Annual report of 1973. Kirov: All-Russian Game Management and Animal Breeding Research Institute. 44 p. [In Russian]
Marakov S.V. 1978. About dynamics of the Commander Islands population of harbor seal. In: Marine mammals: Abstracts of All-Union Seventh Meeting (Simferopol, 20-23 September, 1978). Simferopol. P. 208-209. [In Russian]

Mymrin N.I., Vertyankin V.V., Fomin V.V. 1979. About abundance of marine mammals on the Commander Islands and state of their protection. In: Seal farm of the USSR: Materials of the All-Union Meeting on Rational Organisation of Seal Farming in the Country 1976-1977. Moscow: Central Information Technology and Economy Research Institute in Fisheries. P. 34-36. (Manuscript is stored on 15.05.1979, №229). [In Russian]

Nikulin V.S., Nikulin S.V. 2012. Number of marine mammals on the Severo-Zapadnoe rookery of Bering Island in summer of 2010-2012. In: Biodiversity Conservation of Kamchatka and adjacent seas: Materials of XIII International Scientific Conference (14-15 November, 2012). Petropavlovsk-Kamchatsky: Lamchatpress Publishing House. P. 259-261. [In Russian]

Pauli B.D., Terhune J.M. 1987. Meteorological influences on harbor seal haul-out. Aquatic Mammals 13(3): 114-118.

Pinigin V.E., Pryanishnikov V.G. 1972. Some data on the number of earless seals on the Commander Islands. In: Marine mammals: Abstracts of the Fifth All-Union Meeting. Makhachkala. P. 77-80. [In Russian]

Reder S., Lydersen C., Arnold W., Kovacs K.M. 2003. Haulout behaviour of high Arctic harbour seals (Phoca vitulina vitulina) in Svalbard, Norway. Polar Biology 27(1): 6-16. DOI: 10.1007/s00300-003-0557-1

Reijnders P.J.H. 1982. On the ecology of the harbour seal Phoca vitulina in the Wadden Sea: population dynamics, reside levels, and management. Veterinary Quaterly 4(1): 36-42.

Sergeev M.S. 1938. Soviet islands in the Pacific Ocean. Leningrad: State Socio-Economic Publishing House, Leningrad Branch. 281 p. [In Russian]

Sharples R.J., Mackenzie M.L., Hammond Ph.S. 2009. Estimating seasonal abundance of a central place forager using counts and telemetry data. Marine Ecology Progress Series 378: 289-298. DOI: 10.3354/meps07827

Simpkins M.A., Withrow D.E., Cesarone J.C., Boveng P.L. 2003. Stability in the proportion of harbor seals hauled out under locally ideal conditions. Marine Mammal Science 19(4): 791-805. DOI: 10.1111/j.17487692.2003.tb01130.x

Thompson P.M., Harwood J. 1990. Methods for estimation the population size of common seals, Phoca vitulina. Journal of Applied Ecology 27(3): 924-938. DOI: 10.2307/2404387

Thompson P.M., Tollit D.J., Wood D., Corpe H.M., Hammond P.S., Mackay A. 1997. Estimating harbor seal abundance and status in an estuarine habitat in northeast Scotland // Journal of Applied Ecology 34(1): 43 52. DOI: $10.2307 / 2404846$

Thompson D., Lonergan M., Duck C. 2005. Population dynamics of harbour seals Phoca vitulina in England: monitoring growth and catastrophic declines. Journal of Applied Ecology 42(4): 638-648. DOI: 10.1111/j.13652664.2005.01025.x 
Trukhin A.M. 2009. Current status of pinnipeds in the Sea of Okhotsk. PICES Scientific Report 36: 82-89.

Vaksel S. 1940. Second Kamchatka Expedition of Vitus Bering. Leningrad; Moscow: Glavsevmorputi Publishing House. 174 p. [In Russian]

Vyatkin P.S., Burkanov V.N. 2006. The common seal (Kuril Islands subspecies - Stejneger seal or antur) Phoca vitulina stejnegeri J.Allen, 1902. In: Red Data Book of Kamchatka. Vol. 1: Animals. Petropavlovsk-Kamchatsky. P. 237-238. [In Russian]

Zagrebelny S.V., Fomin V.V. 2012. Population fluctuations and tendencies in the Commander Islands harbor seal (Phoca vitulina stejnegeri) population development.
In: Marine mammals of Holarctic region: Proceedings of the VII International Conference (Suzdal, 24-28 September, 2012). Vol. 1. Suzdal. P. 248-253. [In Russian]

Zagrebelny S.V., Fomin V.V. 2014. Modern state and main tendencies in harbor seals (Phoca vitulina steijnegeri) and spotted seal (Phoca largha) groups development on Bering and Medniy Islands (the Commander Islands). In: A.P. Savelyev, I.V. Seredkin (Eds.): Ranges, migrations and other movements of wild animals: Proceedings of the International Scientific-Practical Conference (Vladivostok, 25-27 November, 2014). Vladivostok: Publisher «REA». P. 96-102. [In Russian]

\title{
НОВЫЙ МЕТОД УЧЕТА ЧИСЛЕННОСТИ РНОСА VITULINA SSP. STEJNEGERI (CARNIVORA, PHOCIDAE) НА КОМАНДОРСКИХ ОСТРОВАХ (РОССИЯ)
}

\author{
Е. Г. Мамаев \\ Государственный природный биосферный заповедник «Командорский», Россия \\ e-mail:eumetopias@mail.ru
}

Дальневосточный подвид обыкновенного тюленя - антур (Phoca vitulina ssp. stejnegeri), является постоянным обитателем прибрежья Командорских островов. Экология вида, и, в частности, особенности жизненного цикла, популяционная структура, уровень рождаемости и многое другое изучены крайне слабо. Подавляющее большинство работ посвящено численности и изучению пространственного распределения вида на островах. В 2017 г. с июня по октябрь на островах Беринга, Топорков и Арий Камень (также, были обследованы Бобровые Камни на о. Медном) была выполнена работа по определению современной численности вида, исследованию особенностей пространственного распределения, установлению репродуктивного успеха командорской группировки антура, сезонной динамики численности и сравнению точности различных методов его учета. Сбор первичного материала по численности и пространственному распределению тюленей проводили с помощью беспилотного летательного аппарата квадрокоптера. На островах учет антура с помощью аэрофотосъемки был проведен впервые. Учет для определения численности популяции проводили в период активной фазы размножения вида - со второй половины июня по 10 июля. Так, учтенная численность антура на о. Беринга и о. Топорков составила 1543 особи, в том числе 343 щенка. Численность антура на о. Медном, рассчитанная методом экстраполяции, оценена в 689 особей, а общая (абсолютная) численность вида на Командорских островах определена в 3344 особи. Впервые для командорской группировки антура были получены данные по доле щенков на залежках в период размножения (22.2\%) и рассчитана удельная рождаемость, которая составила $17.4 \%$. До 69.3\% численности вида представлено в крупных залежках и лишь небольшую долю занимают малочисленные группы или одиночные животные. Доля щенков, родившихся в крупных залежках, составляет $72 \%$. Выявлено возрастание численности антура на залежках в период линьки (август). На отдельных залежках численность продолжила расти и в сентябре. Сравнение точности традиционного на Командорских островах визуального метода учета с данными, полученными по аэрофотосъемкам, показало, что при учете с лодки наблюдатель видит в среднем 67.7\% взрослых животных и 24\% щенков. При наблюдении с берега, с первой приморской террасы, можно заметить 39.6\% тюленей (взрослых и щенков), а при наблюдении со склонов (высота от 17 м и выше) - до 62\%. Для обсуждения многолетней динамики численности вида на Командорских островах требуется проведение детального анализа всех имеющихся данных, как опубликованных, так и архивных, так как они собирались различными методами, сравнивать которые напрямую с вновь полученными результатами не корректно.

Ключевые слова: антур, залежка, Красная книга, метод учета, тюлень, уровень рождаемости, численность 